\title{
CARACTERISATION OF TITANIUM NITRIDE LAYERS DEPOSITED BY REACTIVE PLASMA SPRAYING
}

\author{
Radu Alexandru Roşu ${ }^{1 *}$, Viorel-Aurel Şerban ${ }^{1}$, Alexandra Ioana Bucur ${ }^{2}$, Mihaela Popescu ${ }^{1}$, \\ Dragoş Uţu ${ }^{1}$ \\ ${ }^{I}$ Politehnica University of Timisoara, Romania \\ ${ }^{2}$ National Institute for Research and Development in Electrochemistry and Condensed Matter \\ Timisoara, Romania
}

\begin{abstract}
Forming and cutting tools are subjected to the intense wear solicitations. Usually, they are either subject to superficial heat treatments or are covered with various materials with high mechanical properties. In recent years, thermal spraying is used increasingly in engineering area because of the large range of materials that can be used for the coatings. Titanium nitride is a ceramic material with high hardness which is used to cover the cutting tools increasing their lifetime. The paper presents the results obtained after deposition of titanium nitride layers by reactive plasma spraying (RPS). As deposition material was used titanium powder and as substratum was used titanium alloy (Ti6Al4V). Macroscopic and microscopic (scanning electron microscopy) images of the deposited layers and the $X$ ray diffraction of the coatings are presented. Demonstration program with layers deposited with thickness between 68,5 and 81,4 $\mu$ m has been achieved and presented.
\end{abstract}

Key words: Thermal spraying, Titanium nitride, Surface engineering, Deposited layers

\section{INTRODUCTION}

Surface engineering and coating technology include processes which modify the surface material to improve their behavior, performance, life time and the economic production. This means the modification of the component surface to confer different properties from those of the base materials (substrates) [1]. Life time and performance of basic mechanical components (shafts, gears and other components) are conditioned largely by their geometry and metallurgy, but there are outstanding opportunities to optimize the performance of these components by modifying their

*Corresponding author's email: rrosu@isim.ro 
surface. At the parts subject to wear is possible to reduce the friction and to prolong the life time of the equipment by covering with special materials [2].

Thermal spraying has an increased applicability due to the its numerous advantages. Currently, there are industries where using thermal coating technologies is essential to obtain characteristics required by the users. The most advanced components for use in coated material is noted in particular in the areas of aerospace and automotive industry [3].

Generally, the ceramic materials cannot be used as wires or bars; their use in powder form does not constitute a disadvantage in thermal spraying because the materials used often in this process are powders. On the other hand, using powder ceramic materials their chemical composition can be well diversified, which led to new materials with special properties.

Titanium alloys are increasingly used in many industries (aerospace, aeronautical, medical) due to good corrosion resistance and low specific density than other alloys. The disadvantage of titanium alloys is that they have a low wear resistance. Therefore, their surface is covered with various materials to increase the wear resistance [4]. Titanium nitride (TiN) is a ceramic material which has high hardness and is often used to cover titanium alloys, steel, aluminum substrates to increase the surface characteristics of the components.

The most common applications of titanium nitride coatings is to increase wear and corrosion resistance of the cutting tools (drills, mills) increasing their lifetime more than three times $[5,6]$. This paper presents the experimental results after the deposition of titanium nitride layers using titanium powder by reactive thermal spraying method.

\section{MATERIALS USED}

For experiments pure titanium powder with the particles size ranging between 5 and $15 \mu \mathrm{m}$ was used. As substrate titanium disks $30 \times 5 \mathrm{~mm}$ diameter were used. The samples were blasted with corundum with an average particle size between 0.8 and $2 \mathrm{~mm}$ at the pressure of 5 bar and blasting distance of $50 \mathrm{~mm}$. After the blasting process the samples were cleaned with alcohol.

\section{EQUIPMENT USED FOR THE INVESTIGATION OF THE DEPOSITED LAYERS}

Scanning electron microscope (SEM) Inspect S model coupled with the Energy-dispersive X-ray spectroscopy (EDX) was used to characterize the external surfaces. The phases composition of the deposited layers was realized by $\mathrm{X}$ ray diffraction (XRD) using $\mathrm{X}$ ray diffractometer X'Pert Pro MPD PANalytical. The condition were $45 \mathrm{kV}$ and $30 \mathrm{~mA}$, using copper radiation with the wavelength $\lambda=1.541 \AA$.

The microlayers thickness was performed using Leptoscop Pocket device and the surface roughness determination was made by Surftest 201 (SJ-201) device from Mitutoyo.

\section{EXPERIMENTAL PROCEDURE}

For experiments was used the plasma thermal spraying equipment from National Institute for Research and Development in Welding and Material Testing, ISIM Timisoara supplied by Sulzer Metco. The principle of deposition titanium nitride layers by reactive plasma thermal spraying 
process is based on the chemical reactions which occur during the thermal spraying process. As plasmagen gas nitrogen was used. Also, the transport gas of the powder and for sample cooling was used nitrogen. As a result of chemical reactions between the particles of titanium melted in the plasma gas stream $\left(15000^{\circ} \mathrm{C}\right)$ and nitrogen are obtained TiN compounds with higher hardness compared with the substrate [7].

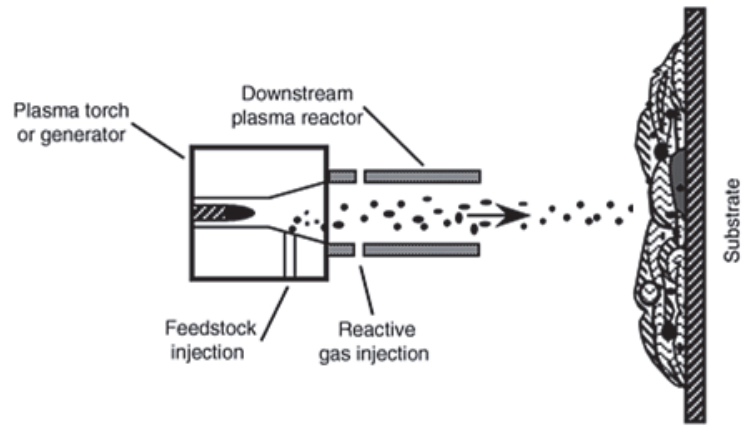

Figure 1 - The principle of reactive plasma spraying process [7]

In table 1 are presented the parameters used to deposit titanium nitride layers by reactive plasma spraying.

Table 1: Parameters used to deposit titanium nitride layers

\begin{tabular}{|c|c|c|c|c|c|c|}
\hline $\begin{array}{c}\mathrm{I}_{\mathrm{p}} \\
{[\mathrm{A}]}\end{array}$ & $\begin{array}{c}\mathrm{U}_{\mathrm{a}} \\
{[\mathrm{V}]}\end{array}$ & $\begin{array}{c}\mathrm{Q}_{\mathrm{P}} \\
{[1 / \mathrm{min}]}\end{array}$ & $\begin{array}{c}\mathrm{Q}_{\mathrm{tr}} \\
{[1 / \mathrm{min}]}\end{array}$ & $\begin{array}{c}\mathrm{m}_{\mathrm{p}} \\
{[\mathrm{g} / \mathrm{min}]}\end{array}$ & $\begin{array}{c}\mathrm{d}_{\mathrm{P}} \\
{[\mathrm{mm}]}\end{array}$ & No of passes \\
\hline $320-330$ & $90-100$ & $40-45$ & $6-7$ & $15-17$ & $150 \pm 5$ & 3 \\
\hline
\end{tabular}

\section{EXPERIMENTAL RESULTS}

\subsection{Macroscopic analysis}

Figure 2 shows the macroscopic aspect of the deposited layers by reactive plasma thermal spraying.

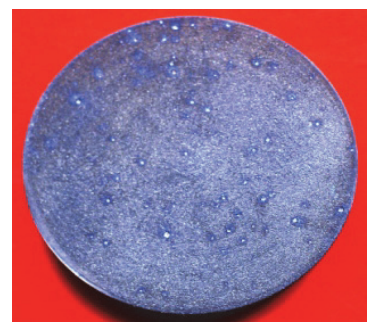

Figure 2 - Macroscopic image of the deposited layers, general view

Journal for Technology of Plasticity, Vol. 36 (2011), Number 1 
The macroscopic analysis shows that deposited layer has spherical voids. This is due to agglomeration of titanium melted powder which reaches the substrate surface at high speed.

\subsection{Microscopic analysis}

The biphasic structure of $\alpha+\beta$ of titanium alloy (Ti6Al4V) used as substrate is presented in figure 3 .

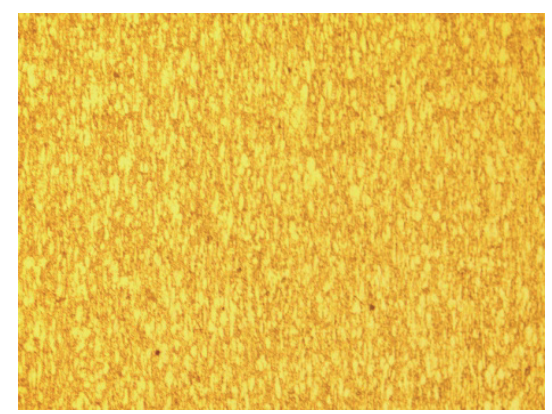

Figure 3 - Microscopic structure of titanium alloy (Ti6Al4V) used as substrate, 200x

Figure 4 presents the SEM images of the deposited layers by reactive plasma thermal spraying method.

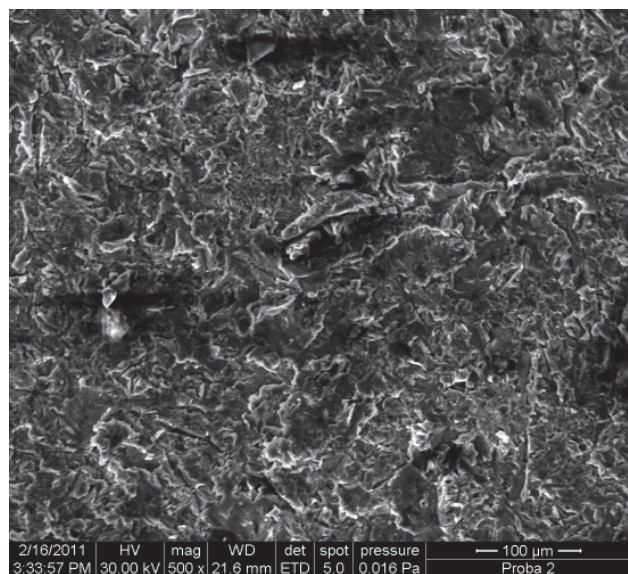

a)

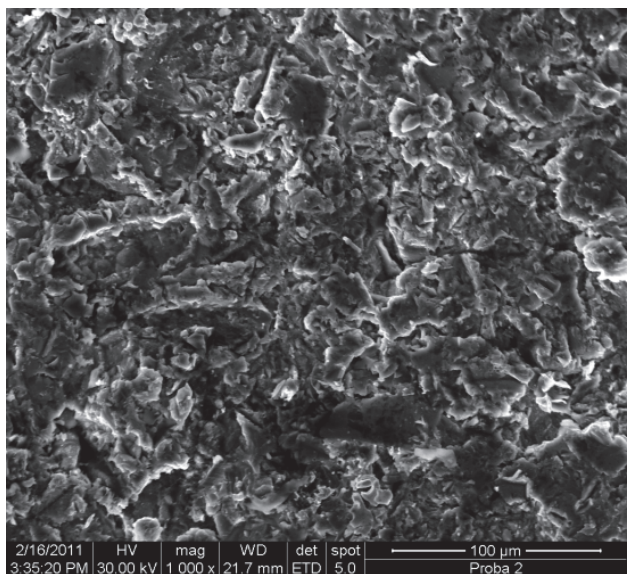

b)

Figure 4 - SEM micrograph of titanium nitride layers deposited by reactive plasma thermal spraying method (a) 500x, (b) $1000 x$

The microscopic analysis shows that the layer is composed of lamellar particles. Also it is observed that the layer has non-uniform presenting pores on the surface of the deposited layers. 


\subsection{Ray diffraction analysis}

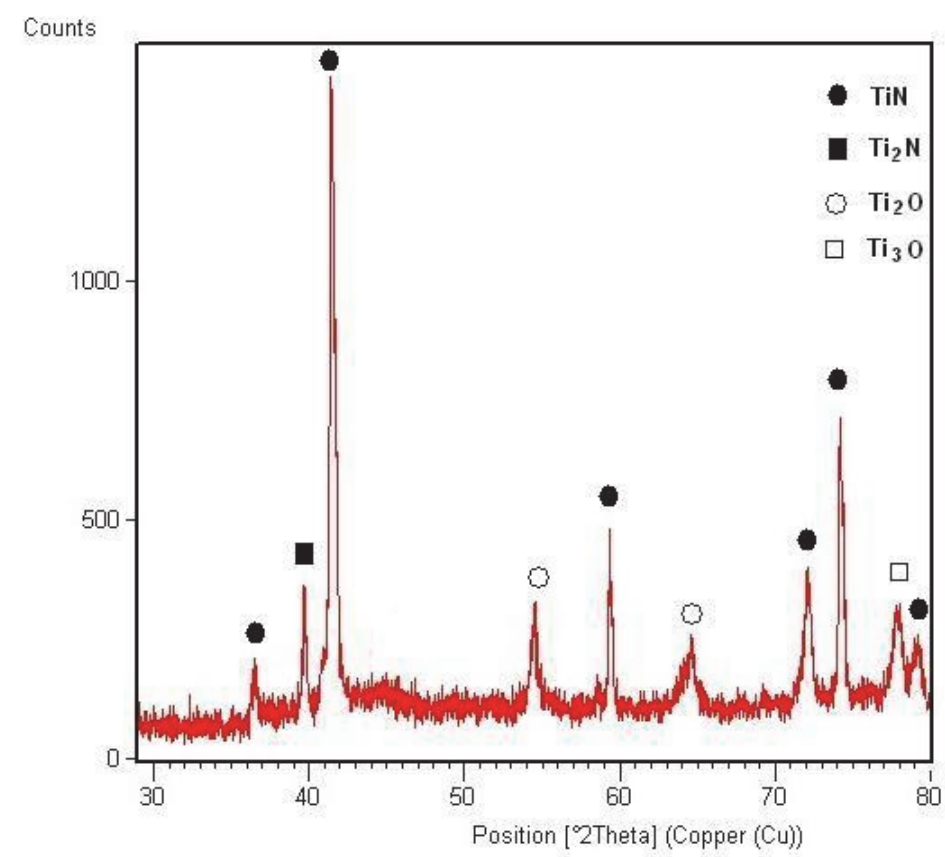

Figure 5 - X ray pattern of titanium nitride layer deposited by reactive plasma spraying

The $\mathrm{X}$ ray diffraction of titanium nitride layer deposited by reactive plasma spraying shows that the layer is composed by titanium nitride $\left(\mathrm{TiN}, \mathrm{Ti}_{2} \mathrm{~N}\right)$ and oxides $\left(\mathrm{Ti}_{2} \mathrm{O}, \mathrm{Ti}_{3} \mathrm{O}\right)$.

\subsection{Layers thickness determination}

The microlayers thickness values performed using Leptoscop Pocket device, are listed in Table 2.

Table 2: Microlayers thickness values

\begin{tabular}{|c|c|}
\hline \multicolumn{2}{|c|}{ Microlayers thickness $[\mu \mathrm{m}]$} \\
\hline Individual values & Mean value \\
\hline 78,$3 ; 68,5 ; 81,4 ; 77,8 ; 79,1$ & 77,02 \\
\hline
\end{tabular}

\subsection{Roughness determination of the deposited layers}

The surface roughness values of the deposited layers by reactive plasma spraying are presented in Table 3 .

Table 3: Roughness values of the deposited layers

\begin{tabular}{|l|c|}
\hline \multicolumn{2}{|c|}{ Average roughness Ra $[\mu \mathrm{m}]$} \\
\hline Individual values & Mean value \\
\hline 5,$43 ; 5,68 ; 5,44 ; 5,98 ; 5,70$ & 5,64 \\
\hline
\end{tabular}




\subsection{Hardness tests}

HV1 microhardness tests were performed on the microlayers surfaces, the microhardness values are summarized in Table 4.

Table 4: Hardness values

\begin{tabular}{|c|c|c|}
\hline \multirow{2}{*}{ No. } & \multicolumn{2}{|c|}{ HV1 Hardness values } \\
\cline { 3 - 3 } & \multirow{2}{*}{ Ti6A14V alloy } & Deposited layer \\
\hline 1 & \multirow{2}{*}{348} & 633 \\
\hline 2 & & 686 \\
\hline 3 & & 641 \\
\cline { 3 - 3 } & & \\
\cline { 3 - 3 } & &
\end{tabular}

\section{CONCLUSIONS}

1. Thermal spraying has an increased applicability due to the numerous advantages, currently, there are industries where using thermal coating technologies is essential to obtain characteristics required by the users

2. The $\mathrm{X}$ ray diffraction of titanium nitride layer deposited by reactive plasma spraying shows that the layer is composed by titanium nitride $\left(\mathrm{TiN}, \mathrm{Ti}_{2} \mathrm{~N}\right)$ and oxides $\left(\mathrm{Ti}_{2} \mathrm{O}, \mathrm{Ti}_{3} \mathrm{O}\right)$.

3. The macroscopic and microscopic analysis shows that the deposited layers by reactive plasma spraying presents thermal defects such as pores. This is due to agglomeration of titanium powder melted which reaches the substrate surface at high speeds.

4. The thickness of the deposited layers by reactive plasma spraying method have values between 68.5 and $79.1 \mu \mathrm{m}$, thickness which posses hardness between 633 and $686 \mathrm{HV} 1$, hardness which ensures a high wear resistant of the components.

\section{ACKNOWLEDGEMENT}

This work was partially supported by the strategic grant POSDRU/89/1.5/S/57649, Project ID 57649 (PERFORM-ERA), co-financed by the European Social Fund - Investing in People, within the Sectoral Operational Programme Human Resources Development 2007-2013.

\section{REFERENCES}

[1] ASM Thermal Spray Society, International Thermal Spray \&Surface Engineering, Vol 1 No 2, 2006.

[2] Clarke A., Partridge A.: A Strategic Review of the Surface Engineering Industry in the UK, 2006.

[3] Kumar A., Chung Y., Moore J., Doll G., Yatsui K., Misra D.: Surface Engineering:Science and Technology, TMS 2002 Annual Meeting in Seattle, Washington, USA, 2002.

[4] Hirokazu, T., Yasutaka, A.: Study of titanium nitride deposition by supersonic plasma spraying, Vacuum 83, 2009, pp 98-101. 
[5] Peng Z., Miao H., Longhao Q., Gong J., Yang S., Liu C.: Microstructure and mechanical properties of titanium nitride coatings for cemented carbide cutting tools by pulsed high energy density plasma, Chinese Science Bulletin Vol. 48 No.13, 2003, pp 1316-1320.

[6] Alessandro V., Walid K., Hassen J.: Titanium Nitride Coating of RF Ceramic Windows by Reactive DC Magnetron Sputtering, Proceedings of EPAC08, Genova, Italy, 2008.

[7] Zou D., Yan D., Xiao L., Dong Y.: Characterization of nanostructured TiN coatings fabricated by reactive plasma spraying, Surface \& Coatings Technology, vol. 202, no. 10, 2008, pp 19281934. 


\title{
KARAKTERIZACIJA SLOJEVA OD TITAN NITRIDA NASTALIH DISPOZICIJOM POMOĆU TEHNOLOGIJE "REACTIVE PLASMA SPRAYING"
}

\author{
Radu Alexandru Roşu ${ }^{1}$, Viorel-Aurel Şerban ${ }^{1}$, Alexandra Ioana Bucur ${ }^{2}$, Mihaela Popescu ${ }^{1}$, \\ Dragoş Uţu ${ }^{1}$ \\ ${ }^{I}$ Politehnica University of Timisoara, Romania \\ ${ }^{2}$ National Institute for Research and Development in Electrochemistry and Condensed Matter \\ Timisoara, Romania
}

\section{REZIME}

Alati za deformisanje i rezanje su izuzetno opterećeni na habanje. Kako bi se povećala njihova otpornost na habanje, oni su najčešće ili termički tretirani ili se na njih nanose slojevi različitih materijala sa višim mehaničkim osobinama. U novije vreme, termalno nanošenje prahom se sve više koristi zbog raznovrsnosti materijala koji mogu biti nanešeni ovim postupkom. Titan nitrid je keramički materijal sa veoma visokom tvrdoćom koji se nanosi na alate kako bi se povećao njihov radni vek. Ovaj rad prikazuje rezultate dobijene nakon depozicije slojeva titan nitrida pomoću "reactive plasma spraying" tehnologije. Kao materijal depozicije je korišćen prah titana sa veličinama čestica od 5-15 $\mu \mathrm{m}$, a kao supstrat legura titana Ti6Al4V. Nanošenje sloja titan nitrida vršeno je pomoću gasa azota. Kao rezultat hemijske reakcije i visoke temperature od $15000{ }^{\circ} \mathrm{C}$ titan se topi $i$ jedini sa azotom, pri čemu se jedinjenje TiN vezuje za supstrat. Difrakcijom $X$ zraka ustanovljeno je da se u nanesenom sloju, pored TiN, nalaze $i$ sledeće jedinjenja: $\mathrm{Ti}_{2} \mathrm{~N}, \mathrm{Ti}_{2} \mathrm{O}, \mathrm{Ti}_{3} \mathrm{O}$. Makro i mikro slike dobijene skening elektronskim mikroskopom ovih nanošenih slojeva su takođe prikazane u radu. Mikroskopske i makroskopske analize pokazuju da slojevi nanešeni ovim postupkom imaju određenu količinu defekata, odnosno pora.

Ključne reči: Termalno nanošenje slojeva, titan nitrid, inženjerstvo površina, depozicija slojeva 